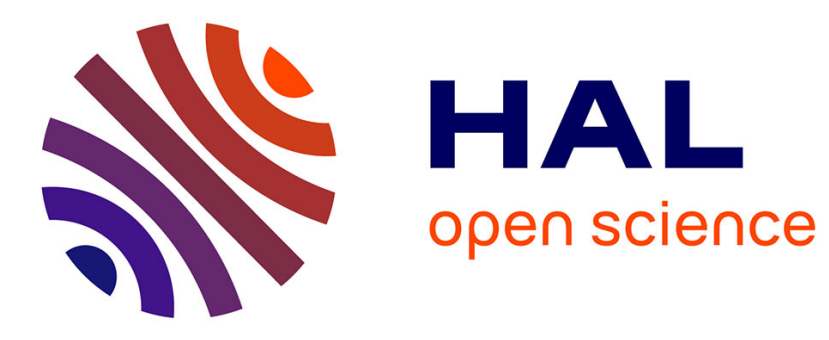

\title{
Influence of the zinc concentration of sol-gel derived zinc substituted hydroxyapatite on cytokine production by human monocytes in vitro
}

\author{
Alexia Grandjean Laquerriere, Patrice Laquerriere, Edouard Jallot, \\ Jean-Marie Nedelec, Moncef Guenounou, Dominique Laurent Maquin, Terry \\ M. Phillips
}

\section{To cite this version:}

Alexia Grandjean Laquerriere, Patrice Laquerriere, Edouard Jallot, Jean-Marie Nedelec, Moncef Guenounou, et al.. Influence of the zinc concentration of sol-gel derived zinc substituted hydroxyapatite on cytokine production by human monocytes in vitro. Biomaterials, 2006, 27, pp.3195-3200. 10.1016/j.biomaterials.2006.01.024 . hal-00154734

\author{
HAL Id: hal-00154734 \\ https://hal.science/hal-00154734
}

Submitted on 14 Jun 2007

HAL is a multi-disciplinary open access archive for the deposit and dissemination of scientific research documents, whether they are published or not. The documents may come from teaching and research institutions in France or abroad, or from public or private research centers.
L'archive ouverte pluridisciplinaire HAL, est destinée au dépôt et à la diffusion de documents scientifiques de niveau recherche, publiés ou non, émanant des établissements d'enseignement et de recherche français ou étrangers, des laboratoires publics ou privés. 


\title{
Influence of the zinc concentration of zinc substituted
}

\section{hydroxyapatite on cytokines production by human}

\section{monocytes in vitro}

\author{
(Accepted in Biomaterials)
}

\begin{abstract}
GRANDJEAN-LAQUERRIERE Alexia ${ }^{1}$, LAQUERRIERE Patrice ${ }^{2-3 \#}$, JALLOT Edouard ${ }^{4}$, NEDELEC Jean-Marie ${ }^{5}$, and PHILIPS Terry M. ${ }^{1}$
\end{abstract}

1. Ultramicro Analytical Immunochemistry Resource, Division of Bioengineering \& Physical Science, Office of Research Services, National Institutes of Health, Bethesda, MD, 20892, USA.

2. Supramolecular Structure and Function Resource, Division of Bioengineering \& Physical Science, Office of Research Services, National Institutes of Health, Bethesda, MD, 20892, USA.

3. INSERM - ERM 0203, IFR 53, Laboratoire de Microscopie Electronique, 21, rue Clément Ader, BP 138, 51685 Reims, Cedex 2, France.

4. Laboratoire de Physique Corpusculaire de Clermont-Ferrand CNRS/IN2P3 UMR 6533. Université Blaise Pascal - 24 avenue des Landais, 63177 Aubiere Cedex, France.

5. Laboratoire des Matériaux Inorganiques CNRS UMR 6002. Université Blaise Pascal - 24 avenue des Landais, 63177 Aubiere Cedex, France.

\# corresponding author and current adress : Patrice LAQUERRIERE, INSERM ERM 0203, 21 rue Clément Ader, BP 138, 51685 REIMS cedex, France

Tel : (33) 3.26.05.07.50 Fax : (33) 3.26.05.19.00

e-mail : patrice.laquerriere@univ-reims.fr 


\begin{abstract}
A possible complication associated with the implantation of HA-based prosthesis is the release of particles. Those particles can be phagocyted by monocytes that are among the first cells to colonize the inflammatory site. The activated monocytes produce inflammatory mediators such as cytokines that cause osteoclasts activation. The present work studies the effect of zinc-substituted hydroxyapatite particles with various concentrations of zinc on cytokines production (TNF- $\alpha$, IL-1 $\beta$, IL-6, IL-10, and IL-8) by human monocytes LPSstimulated or not. The concentrations used were $0.5 \%, 1 \%, 2 \%$, and $5 \%$. Our data demonstrates that the zinc has an effect on cytokines production. It decreases the production of TNF- $\alpha$ and increases the production of IL-8 by unstimulated cells. Using LPS-stimulated cells, it decreases the production of inflammatory cytokines and increases the production of anti-inflammatory cytokine (IL-10). So zinc-substituted hydroxyapatite has favourable effects on the cytokines production by monocytes.
\end{abstract}

Keywords : hydroxyapatite particles, cytokines, inflammation, zinc, monocytes. 


\section{Introduction}

Hydroxyapatite (HA) is widely used as biomaterials to filled bone defect or to coat metal parts of prosthesis. The early dissolution of the amorphous phase of the coating during the bone remodelling leads to the release of calcium phosphate particles having various characteristics and compositions [1-3], even when dense HA is used [4]. It has been demonstrated that the interaction between HA particles and human monocytes leaded to the release of inflammatory cytokines such as Tumor Necrosis Factor alpha (TNF- $\alpha$ ), Interleukin 6 (IL-6) [5] or Interleukin 18 (IL-18) [6] and metalloproteinases [7]. Anti-inflammatory cytokines like Interleukin 10 (IL-10) are also produced [5] and it was shown to inhibit IL-6 and TNF- $\alpha$ production following phagocytosis of polymethymetacrylate particles by monocytes/macrophages [8].

Monocytes were used for those studies because analysis of retrieved tissues associated with failed implants, suggest that phagocytosis of HA wear debris provides a potent stimulus for the release of a variety of cytokines [2]. These products are likely responsible for the granulomatous inflammation and disturbance in the bone remodelling that lead to the local osteolytic process. This could potentially lead to the induction of a local particle-induced inflammatory reaction that could adversely affect the integrity of the bone-implant interface [9].

To decrease the inflammatory reaction induced by the phagocytosis of HA particles, we have elaborated zinc-substituted hydroxyapatite. Zinc is naturally present in bone [10]. It has been demonstrated that zinc stimulates bone growth and bone mineralization [11-13]. Zinc has a direct effect on osteoblastic cells in vitro [14] and a potent inhibitory effect on osteoclatic bone resorption [15]. Zinc is also known to modify the production of cytokines [16]. 
Moreover, it has been demonstrated using zinc-substituted HA that the bioactivity was modify by the presence of $5 \%$ of zinc [17].

In the present study, we address three questions: (i) what is the effect of the zinc concentration on the inflammatory reaction, (ii) on the down regulation by IL-10 of the inflammatory reaction, (iii) and on the chemotaxis process (i.e. Interleukin 8 (IL-8) production).

\title{
Materials and methods
}

\author{
Cell culture
}

THP-1 human monocytes were used to evaluate cytokines synthesis. Cells were maintained in RPMI-1640 medium (Lifetechnology, USA) supplemented with 10\% fetal calf serum (Lifetechnology, USA), 2mM glutamine, penicillin (5000 $\mathrm{U}_{\mathrm{m}} \mathrm{ml}^{-1}$ ) and streptomycin (25 $\mu \mathrm{g} \cdot \mathrm{ml}^{-1}$ ) at $37^{\circ} \mathrm{C}$ in a saturated $5 \% \mathrm{CO}_{2} 95 \%$ air atmosphere. The cells were cultured in 6wells plates (Lifetechnology, USA). The density was $2.10^{5}$ cells. $\mathrm{ml}^{-1}$ in a 5 -ml total volume. Cells were exposed or not (control cells) during 6 or 24 hours (time chosen to have an interaction between cells and particles) to the different particles described below. Experiments were made in triplicate. THP-1 were exposed to LPS $\left(1 \mu \mathrm{g} . \mathrm{ml}^{-1}\right)$ (Sigma, USA) as a positive control and to evaluate the effect of zinc-substituted HA on stimulated cells.

The viability of cells was evaluated by trypan blue exclusion test. The viability was $>95 \%$ in all of the experiments (before and after exposure to particles). 
To produce $2 \mathrm{mg}$ of pure HA powder, $4.7 \mathrm{~g}$ of $\mathrm{Ca}\left(\mathrm{NO}_{3}\right)_{2} .4 \mathrm{H}_{2} \mathrm{O}$ (Aldrich, USA), $0.84 \mathrm{~g}$ of $\mathrm{P}_{2} \mathrm{O}_{5}$ (Avocado Research chemicals, UK) were dissolved in ethanol under stirring and under reflux at $85^{\circ} \mathrm{C}$ during $24 \mathrm{~h}$. Then, this solution was heated at $55^{\circ} \mathrm{C}$ during $24 \mathrm{~h}$, to obtain a white consistent gel and at $80^{\circ} \mathrm{C}$ during $10 \mathrm{~h}$ to obtain a white powder. Finally, the powder was heated at $1100^{\circ} \mathrm{C}$ during $15 \mathrm{~h}$. To prepare $\mathrm{Zn}$-substituted hydroxyapatite, $\mathrm{Zn}\left(\mathrm{NO}_{3}\right)_{2} \cdot 6 \mathrm{H}_{2} \mathrm{O}$ (Acros Oraganics, UK) was added to the solution. Four Zn-substituted hydroxyapatites were prepared with Zn-substitution of $0.5,1,2$ and 5\% (respectively noted: HA0.5\%, HA1\%, HA2\%, HA $5 \%$ ).

The chemical composition of the hydroxyapatite powders (Table 1) were determined by ICPAES (Inductively Coupled Plasma-Atomic Emission Spectrometry).

The nature of the crystal phase was determined by powder X-ray diffraction (XRD) using a monochromatic $\mathrm{Cu} \mathrm{K}$ radiation. The samples were scanned in the $2 \theta$ range of $10-70^{\circ}$. X-ray diffraction patterns exhibited the peaks corresponding to hydroxyapatite. A small amount of tricalcium phosphate was observed.

\section{Surface area ratio method}

In the present work, the surface area ratio $(\mathrm{SAR}=$ surface area of material/surface area of cell) method was used. Using this method, a non-uniform challenge may result if particles of varying sizes and surface area are being compared. Since monocytes-macrophages interact with surfaces of both non-phagocytable and phagocytable materials, it is more logical to challenge cells based on the surface areas of the particles. Some authors used a weight percentage, volume percentage or number of particles to perform their studies. Previous studies used this methods with good results [18-19]. From all these data, we have chosen a surface area ratio equal to 1 for our experiments. 
Quantitation of cytokines by ELISA

After 6 and 24 hours, TNF $\alpha$, IL-1 $\beta$, IL-6, IL-8 and IL-10 determinations in cell culture supernatants were performed using commercially available ELISA kits (Quantikine, R\&D Systems, Inc., Minneapolis, MN) according to the manufacturer's instructions. The sensitivity of each kit was $4.4 \mathrm{pg} \cdot \mathrm{ml}^{-1}$ for TNF- $\alpha, 2.2 \mathrm{pg} \cdot \mathrm{ml}^{-1}$ for IL-1 $\beta, 0.70 \mathrm{pg} \cdot \mathrm{ml}^{-1}$ for IL-6, $10 \mathrm{pg} \cdot \mathrm{ml}^{-1}$ for IL-8 and 3.9 pg.ml ${ }^{-1}$ for IL-10. Results are presented in pg. $\mathrm{ml}^{-1}$ for each cytokine studied. No statistical analysis was performed because three experiments are not enough even for a non-parametrical test.

\section{Results}

\section{Effect of HA particles on TNF- $\alpha$ production}

In order to investigate how zinc-substituted HA particles with zinc at different concentrations modulate TNF- $\alpha$ synthesis, THP-1 cells were incubated with different HA particles for 6 and 24 hours. After 6 and 24 hours, the level of TNF- $\alpha$ protein was not detected in control cells (figure 1a). Using LPS, the production of TNF- $\alpha$ was maximum at both 6 and 24 hours. The production of TNF- $\alpha$ by THP-1 increased when cells were exposed to pure HA and zincsubstituted HA particles. But the production induced by the particles remained 20 times less than the production induced by LPS.

Due to the low production of TNF- $\alpha$ induced by the HA particles, we have stimulated cells with LPS to investigate if the concentration of zinc had an influence on TNF- $\alpha$ production (figure 1b). The addition of pure HA particles to THP-1 stimulated by LPS increase the 
production of TNF- $\alpha$ at both 6 and 24 hours. But using zinc-substituted HA particles, the production of TNF- $\alpha$ did not change compared to cells stimulated with LPS without any HA particles.

So the presence of pure HA particles increase slightly the production of TNF- $\alpha$ by THP-1. The presence of zinc-substituted HA particles slightly decreased the production of TNF- $\alpha$ by unstimulated cells.

\section{Effect of HA particles on $I L-1 \beta$ production}

We next studied how HA particles modulate another inflammatory cytokine, IL-1 $\beta$ : THP-1 were incubated with different HA particles during 6 and 24 hours.

We did not detect the production of IL-1 $\beta$ in the control cells (figure $2 a$ ). The production of IL-1 $\beta$ was important using THP-1 stimulated by LPS at both 6 and 24 hours. When cells were exposed to zinc-substituted HA or to pure HA a particle, the production of IL-1 $\beta$ was not detected.

When cells were stimulated by LPS, the most important production was obtained at both 6 and 24 hours using pure HA particles, it was even higher than LPS-stimulated cells (figure $2 b)$. At 6 and 24 hours, the production of IL-1 $\beta$ by THP-1 cells was the same whatever was the zinc concentration and it was lower than using pure HA particles.

So the presence of HA particles did not modify the production of IL-1 $\beta$ by unstimulated THP1. But the production of IL-1 $\beta$ by LPS-stimulated THP-1 was increased by addition of pure HA particles and it decreased when zinc-substituted HA was used.

\section{Effect of HA particles on IL-6 production}


We next adressed the role of HA particles on the production of IL- 6 by THP-1 and LPSstimulated THP-1.

We did not detect the production of IL-6 in the control cells (figure 3a). The production of IL6 was important using THP-1 stimulated by LPS at both 6 and 24 hours. The production of IL-6 was not detected when cells were exposed to pure HA or zinc-substituted HA at 6 and 24 hours.

At 6 hours, when cells were stimulated by LPS, the production of IL- 6 was the same with all kind of HA particles (figure 3b). At 24 hours, the production of IL-6 was the same using pure HA, zinc-substituted HA with $0.5,1$, and $2 \%$ of zinc. The production decreased using HA containing $5 \%$ of zinc.

In summary, pure HA or zinc-substituted HA particles did not modify the production of IL-6 by stimulated or not-stimulated THP-1 except at the concentration of $5 \%$. In this case, the IL6 production was decreased.

\section{Effect of HA particles on IL-10 production}

The production of IL-10 was next studied to evaluate if the presence of HA particles modulate the anti-inflammatory cytokine production.

At 6 and 24 hours, IL-10 production was not detected in the control cells (figure 4a). Addition of LPS allow the production of IL-10 by THP-1. At 6 and 24 hours, no production of IL-10 was detected when cells were exposed to pure HA or zinc-substituted HA particles.

Using HA particles, the production of IL-10 by LPS-stimulated THP-1 increased and was different in function of the concentration of zinc (figure 4b). At 6 and 24 hours, the concentration of IL-10 was almost the same using zinc-substituted HA with $0.5 \%, 1 \%$, and 
$2 \%$ of zinc. It slightly increased using pure HA and the concentration was maximum using zinc-substituted HA particles containing $5 \%$ of zinc.

To summarize, the production of IL-10 was not detected when unstimulated THP-1 was used. After stimulation, addition of pure HA or zinc-substituted HA particles increased the production. The maximum was obtained using a zinc concentration of $5 \%$.

Effect of HA particles on IL-8 production

Finally, we studied the production of the chemokine IL-8 by THP-1 using HA particles to evaluate the recruitment of cells induced by the presence of the various HA particles.

After 6 and 24 hours, the production of IL-8 by cells without any stimulation was low (figure 5a). Using LPS, the production was important. At 6 and 24 hours, the production of IL-8 seemed to be a function of the zinc concentration in HA particles: the lowest production was observed without zinc and the production increased with the concentration of zinc.

The production of IL-8 by LPS-stimulated cells was the same using pure HA or zincsubstituted HA particles at both 6 and 24 hours (figure 5b).

In conclusion, the production of IL-8 by unstimulated THP-1 increased with the concentration of zinc. No modification of the production of IL-8 was observed when LPS-stimulated cells were exposed or not to HA particles.

\section{Discussion}

Data presented here show that HA particles can induce cytokine production by THP-1 and LPS-stimulated THP-1 depending on the concentration of zinc. By studying TNF- $\alpha$, IL-1 $\beta$, IL-6, IL-8, and IL-10 production by unstimulated and LPS-stimulated cells, we addressed 
three major questions : (i) what is the effect of the concentration of zinc on the inflammatory reaction (ii) does there exist a down regulation of the inflammatory response by cells and (iii) does the zinc modify the chemotaxis process?

Production of inflammatory cytokines by LPS-stimulated or unstimulated cells was modify by the presence of pure HA or zinc-substituted HA particles. When unstimulated cells were used, no IL-1 $\beta$ and IL-6 were detected. Only the production of TNF- $\alpha$ was modified by hydroxyapatite particles substituted with different zinc concentrations. In this case the maximum of TNF- $\alpha$ detected was observed using HA particles without any zinc and its level decreased with the zinc concentration. When LPS-stimulated cells were used, the zinc had an effect on the inflammatory cytokines production: the highest concentration of zinc decreased the production of TNF- $\alpha$ and IL-1 $\beta$. No quantifiable effect of the zinc concentration was observed on the production of IL-6. Previous study has already demonstrated that zinc modulates mRNA levels of cytokines [16]. In this paper, the authors observed that zinc deficiency increased the mRNA levels of TNF- $\alpha$, IL-1 $\beta$, and IL-8 of PMA-stimulated HL 60 (monocyte-macrophage cell line). They also demonstrated that the effect of zinc depended on the cell lineage. In our work, we can add that the effect of zinc depends also on the cytokine study : zinc had no effect on IL-6 production. Recent work has also demonstrated an effect of zinc concentration $(7,5$ and $15 \%)$ in bioactive glasses on cytokines production [20]. They demonstrated that highest concentrations of zinc than used in the present work did not modify the production of TNF- $\alpha$ and IL- 6 by unstimulated primary macrophages. But the production of IL-10 slightly increased with the concentration of zinc. Still in this paper, authors also used LPS stimulated macrophages. They observed no difference in the production of TNF- $\alpha$, IL-6, or IL-10 whatever was the zinc concentration. 
IL-10 is an important immunoregulatory cytokine produced by several cell populations. Its main biological role is thought to be the limitation and the termination of infmammatory response and the regulation of differentiation and proliferation of immune cells. In the present work, the presence of pure HA or zinc-substituted HA particules did not induce the production of this cytokine. But after LPS stimulation the production of IL-10 increased with the zinc concentration. Day et al [21] has also observed an increase of IL-10 production by human macrophages/monocytes exposed to bioactif glass particles containing 7.5 and $15 \%$ of zinc.

The production of IL- 8 was studied to evaluate the recruitment of cells induced by the presence of the different HA particles. The increase of the zinc concentration induced an augmentation of the release of IL-8. So the chemotaxis process might be changed by the presence of zinc in the hydroxyapatite. This is in contradiction with one report that suggested that zinc-sufficient conditions decreased generation of IL-8 in endothelial cells [21].

It is known that patients with inflammatory diseases such as rheumatoid arthrisis, who have low blood zinc level, show increased TNF- $\alpha$ production [22]. But these manifestations can be reversed by zinc supplementation [23-24]. In our study, zinc concentration has positive effects on cytokines production.

In conclusion, zinc-substituted hydroxyapatite had an effect on the production of cytokines by human monocytes cells. The production of TNF- $\alpha$ by unstimulated cells decreased with the zinc concentration. Still on unstimulated cells, the production of IL-8 increased so chemotaxis is improved with the increase of zinc concentration. Using LPS-stimulated cells, the production of IL-1 $\beta$ and IL-6 decreased when zinc-substituted HA particles were used. So the inflammatory reaction is decreased compared to pure hydroxypapatite particles. The production of IL-10 by stimulated cells increased with the concentration of zinc. 
So zinc has positive effects: it decreases the inflammatory reaction, increases the chemotaxis and the down-regulation of the inflammatory reaction. 
References :

[1] Bloebaum RD, DuPont JA. Osteolysis from press-fit hydroxyapatite-coated implant. J Arthroplasty 1993;8:195-202.

[2] Bloebaum RD, Beeks, Dorr LD, Savory CG, DuPont JA, Hofmann AA. Complications with hydroxyapatite particulate separation in total hip arthoplasty. Clin Orthop 1994;298 : 1926

[3] Bloebaum RD, Zou L, Bachus KN, Shea KG, Hofmann AA, Dunn HK. Analysis of particulates in acetabular components from patient with osteolysis. Clin Orthop 1997;338:109-118.

[4] Benhayoune H, Jallot E, Laquerriere P, Balossier G, Bonhomme P, Frayssinet P. Integration of HA dense rods into cortical bone. Biomaterials 2000;21 : 235-242.

[5] Laquerriere P, Grandjean-Laquerriere A, Jallot E, Balossier G, Frayssinet P and Guenounou M. Importance of hydroxyapatite particles characteristics on cytokines production by human monocytes in vitro. Biomaterials 2003, 24: 2739-2747.

[6] Grandjean-Laquerriere A., Laquerriere P., Laurent-Maquin D., Guenounou M., Phillips T.M. IL-18 production by human monocytes in vitro in presence of differents hydroxyapatite particles : importance of physical characteristics Biomaterials 2004, 25(28) : 5921-5927.

[7] Laquerriere P, Grandjean- Laquerriere A, Addadi-Rebbah S, Jallot E, Lauernt-Maquin D, Frayssinet P, Guenounou M. MMP-2, MMP-9 and their inhibitors TIMP-2 and TIMP-1 production by human monocytes in vitro in presence of differents hydroxyapatite : importance of particle physical characteristics. Biomaterials 2004, 25: 2515-2524.

[8] Trindade MCD, Lind M, Nakashima Y, Sun D, Goodman SB, Schurman DJ, Smith RL. Interleukin-10 inhibits polymethymethacrylate particle induced interleukin-6 and tumor 
necrosis factor- $\alpha$ release by human monocytes/macrophages in vitro. Biomaterials $2001 ; 22$ : 2067-2073.

[9] Haynes DR, Roger SD, Hay S, Pearcy MJ, Howie DW. The differences in toxicity and release of bone-resorbing mediators induced by titanium and cobalt-chromium-alloy wear particles. J Bone Joint Surg 1993;75A : 825-834.

[10] Jallot E., Irigaray J.L., Oudadesse H., Brun V., Weber G., Frayssinet P. Resorption cinetics of four hydroxyapatite-based ceramics by PIXE and neutron activation analysis. Eur. Phys. J. AP. $1999 ; 6$ : 205-215.

[11] Yamaguchi M., Inamoto K., Suketa Y. Effect of essential trace metals on bone metabolism in weanling rats: comparison with zinc and other metals' actions. Res Exp Med. 1986;186(5):337-342.

[12] Yamaguchi M., Oishi H., Suketa Y. Stimulatory effect of zinc on bone formation in tissue culture. Biochem Pharmacol. 1987;36(22):4007-4012

[13] Yamaguchi M., Oishi H., Suketa Y. Zinc stimulation of bone protein synthesis in tissue culture. Activation of aminoacyl-tRNA synthetase. Biochem Pharmacol. 1988;37(21):40754080.

[14] Hashizume M., Yamaguchi M. Stimulatory effect of beta-alanyl-L-histidinato zinc on cell proliferation is dependent on protein synthesis in osteoblastic MC3T3-E1 cells. Mol Cell Biochem. 1993;122(1):59-64.

[15] Kishi S., Yamaguchi M. Inhibitory effect of zinc compounds on osteoclast-like cell formation in mouse marrow cultures. Biochem Pharmacol. 1994;48(6):1225-1230.

[16] Bao B., Prasad A.S., Beck F.W., Godmere M. Zinc modulates mRNA levels of cytokines. Am J Physiol Endocrinol Metab. 2003;285(5):E1095-102.

[17] Jallot E., Nedelec J.M., Grimault A.S., Chassot E., Grandjean-Laquerriere A., Laquerriere P., Laurent-Maquin D. STEM and EDXS characterisation of physico-chemical 
reactions at the periphery of zinc-substituted hydroxyapatite during interactions with biological fluids. Colloid Surf B 2005, in press.

[18] Laquerriere P, Grandjean-Laquerriere A, Killian L, Beorchia A, Guenounou M, Jallot E, Frayssinet P, Balossier G. Influence of Hydroxyapatite Particle Characteristics on the $[\mathrm{K}] /[\mathrm{Na}]$ ratio : a Human Monocytes In Vitro Study. Colloid Surf B 2004, 33 : 49-55

[19] Grandjean-Laquerriere A., Laquerriere P., Guenounou M., Laurent-Maquin D., Phillips T.M. Importance of the surface area ratio on cytokines production by human monocytes in vitro induced by various hydroxyapatite particles. Biomaterials. 2005;26(15):2361-2369.

[20] Day R.M., Boccaccini A.R. Effect of particulate bioactive glasses on human macrophages and monocytes in vitro. J. Biomed. Mater. Res. A. 2005;73A(1):73-79.

[21] Connell P., Young V.M., Toborek M., Cohen D.A., Barve S., McClain C.J., Hennig B. Zinc attenuates tumor necrosis factor-mediated activation of transcription factors in endothelial cells. J. Am. Coll. Nutr. 1997;16(5):411-417.

[22] Zoli A., Altomonte L., Caricchio R., Galossi A., Mirone L., Ruffini M.P., Magaro M. Serum zinc and copper in active rheumatoid arthritis: correlation with interleukin 1 beta and tumour necrosis factor alpha. Clin Rheumatol. 1998;17(5):378-382.

[23] Falchuk K.H. The molecular basis for the role of zinc in developmental biology. Mol Cell Biochem. 1998;188(1-2):41-48.

[24] Wellinghausen N., Rink L. The significance of zinc for leukocyte biology. J Leukoc Biol. 1998;64(5):571-7. 


\section{Captions :}

Table 1 : Theoretical and experimental concentrations (weight \%) of $\mathrm{Ca}, \mathrm{P}, \mathrm{Zn}$ in $\mathrm{HA}$, HA $0.5 \%$, HA $1 \%$, HA $\%$ and HA $5 \%$ determined by ICP-AES.

Figure 1:

a) production of TNF- $\alpha$ by THP-1 exposed to zinc-substituted particles

b) production of TNF- $\alpha$ by LPS-stimulated THP-1 exposed to zinc-substituted particles

Figure 2 :

a) production of IL-1 $\beta$ by THP-1 exposed to zinc-substituted particles

b) production of IL-1 $\beta$ by LPS-stimulated THP-1 exposed to zinc-substituted particles

Figure 3 :

a) production of IL- 6 by THP-1 exposed to zinc-substituted particles

b) production of IL-6 by LPS-stimulated THP-1 exposed to zinc-substituted particles

Figure 4 :

a) production of IL-10 by THP-1 exposed to zinc-substituted particles

b) production of IL-10 by LPS-stimulated THP-1 exposed to zinc-substituted particles

Figure 5 :

a) production of IL-8 by THP-1 exposed to zinc-substituted particles

b) production of IL-8 by LPS-stimulated THP-1 exposed to zinc-substituted particles 


\begin{tabular}{|c|c|c|c|c|c|}
\hline & HA & HA0.5\% & HA1\% & HА $2 \%$ & НА $5 \%$ \\
\hline Ca theoretical & 39.88 & 39.63 & 39.38 & 39.88 & 37.41 \\
\hline Ca experimental & $38.46 \pm 1.92$ & $38.33 \pm 1.92$ & $37.23 \pm 1.86$ & $38.13 \pm 1.91$ & $36.81 \pm 1.84$ \\
\hline $\mathbf{P}$ theoretical & 18.50 & 18.48 & 18.45 & 18.41 & 18.27 \\
\hline P experimental & $17.21 \pm 0.86$ & $17.51 \pm 0.88$ & $17.75 \pm 0.89$ & $17.61 \pm 0.88$ & $17.08 \pm 0.85$ \\
\hline Zn theoretical & - & 0.5 & 1 & 2 & 5 \\
\hline Zn experimental & - & $0.45 \pm 0.03$ & $0.90 \pm 0.05$ & $1.79 \pm 0.08$ & $4.59 \pm 0.23$ \\
\hline
\end{tabular}




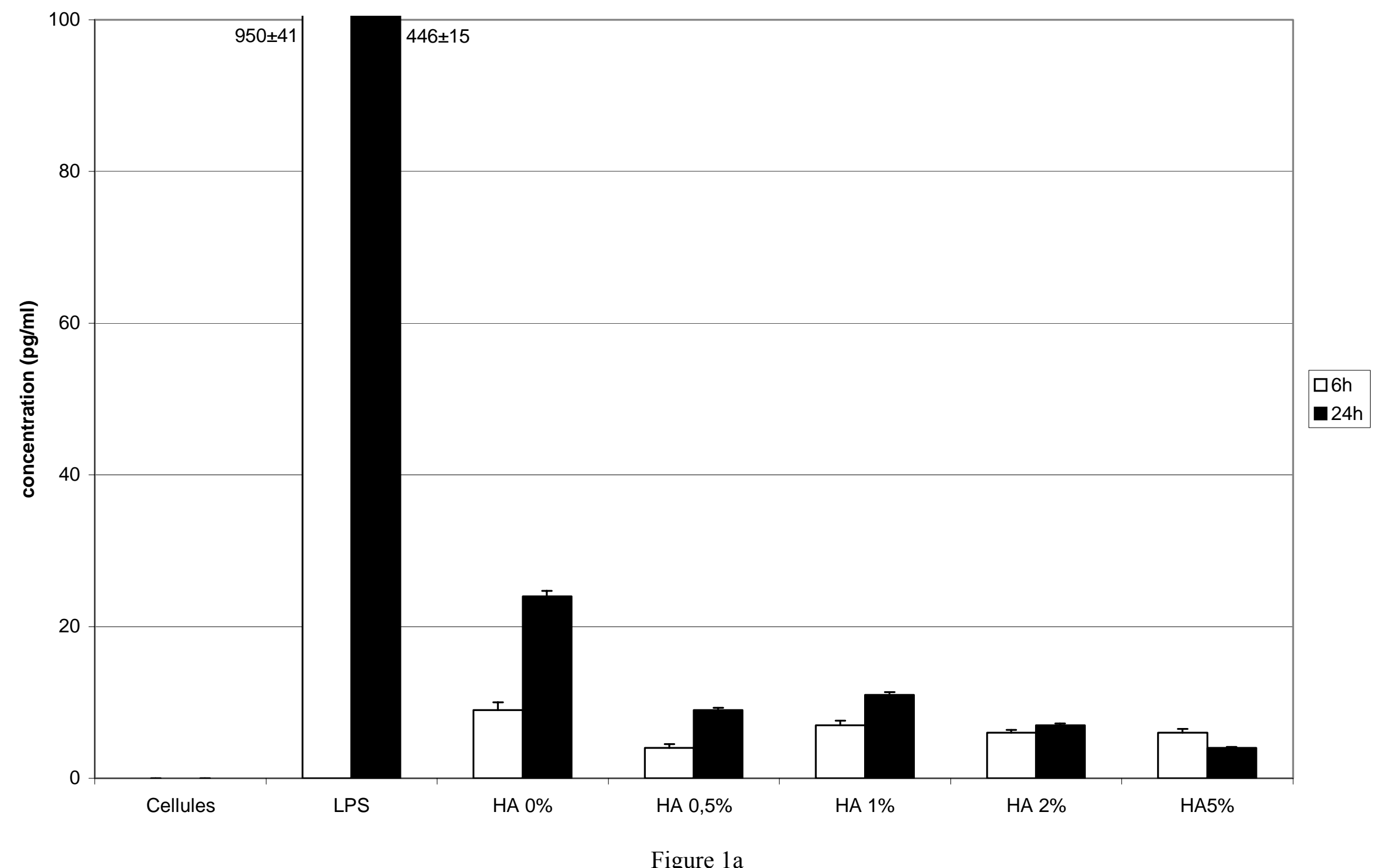




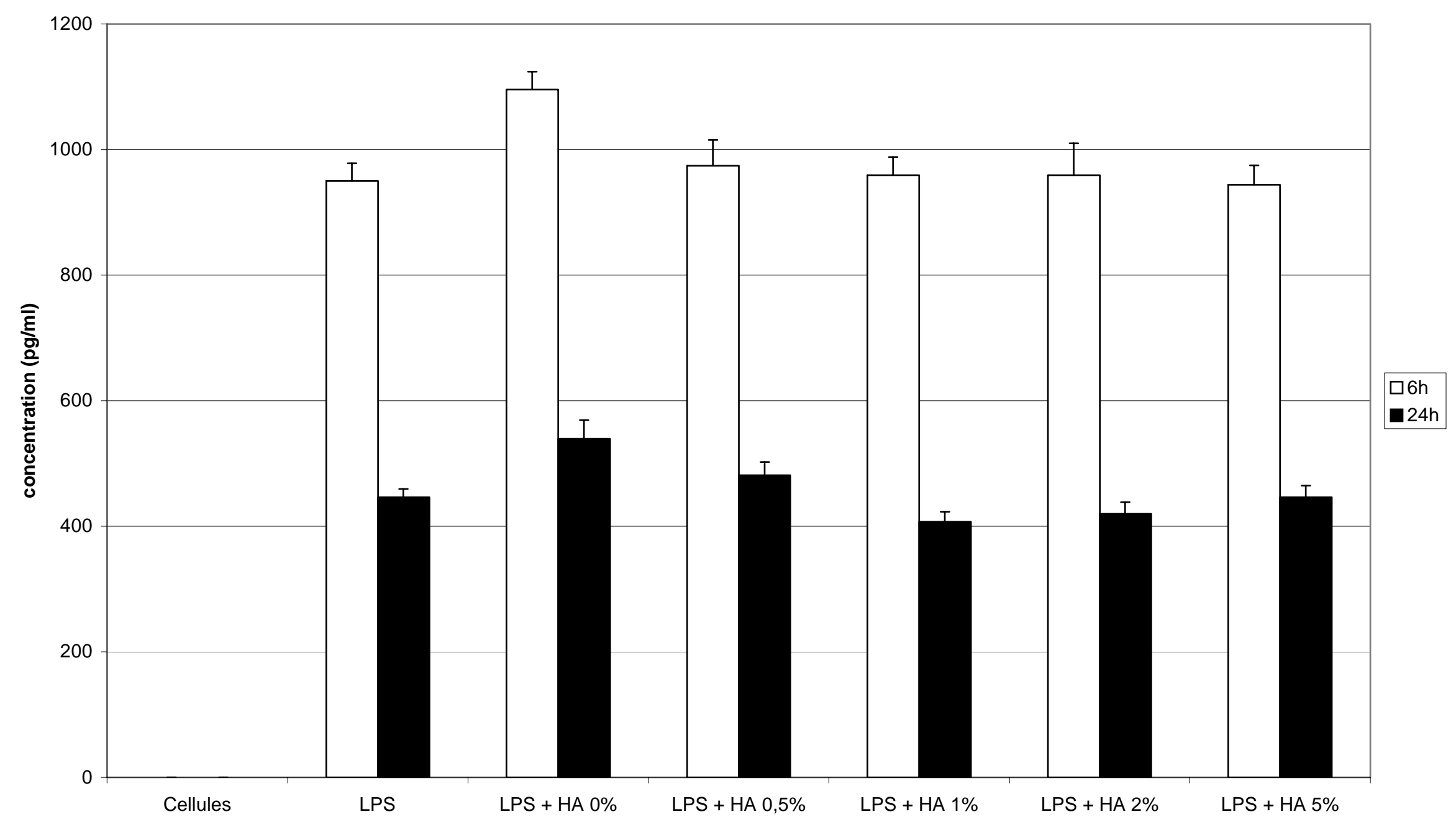

Figure 1b 


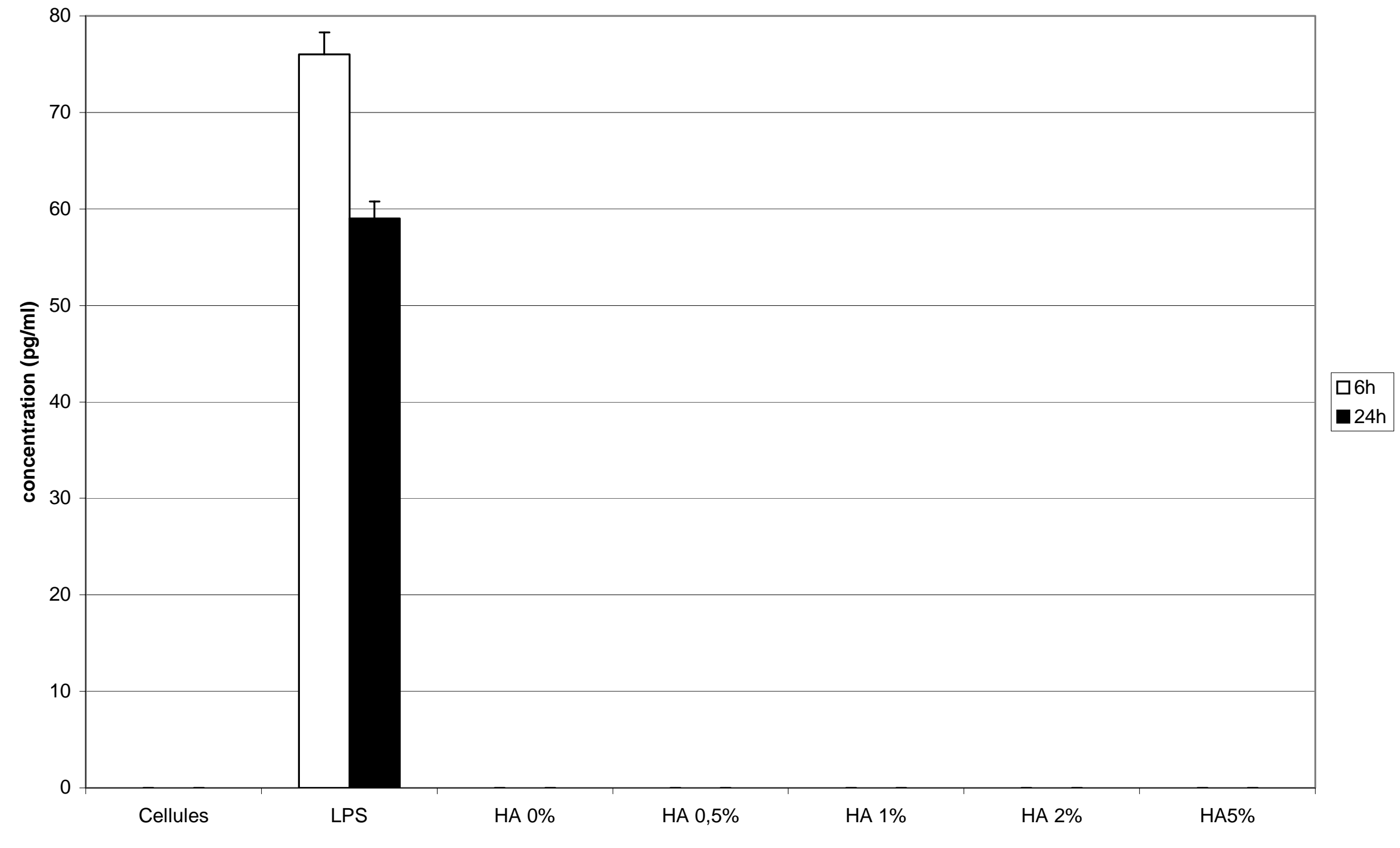

Figure 2a 


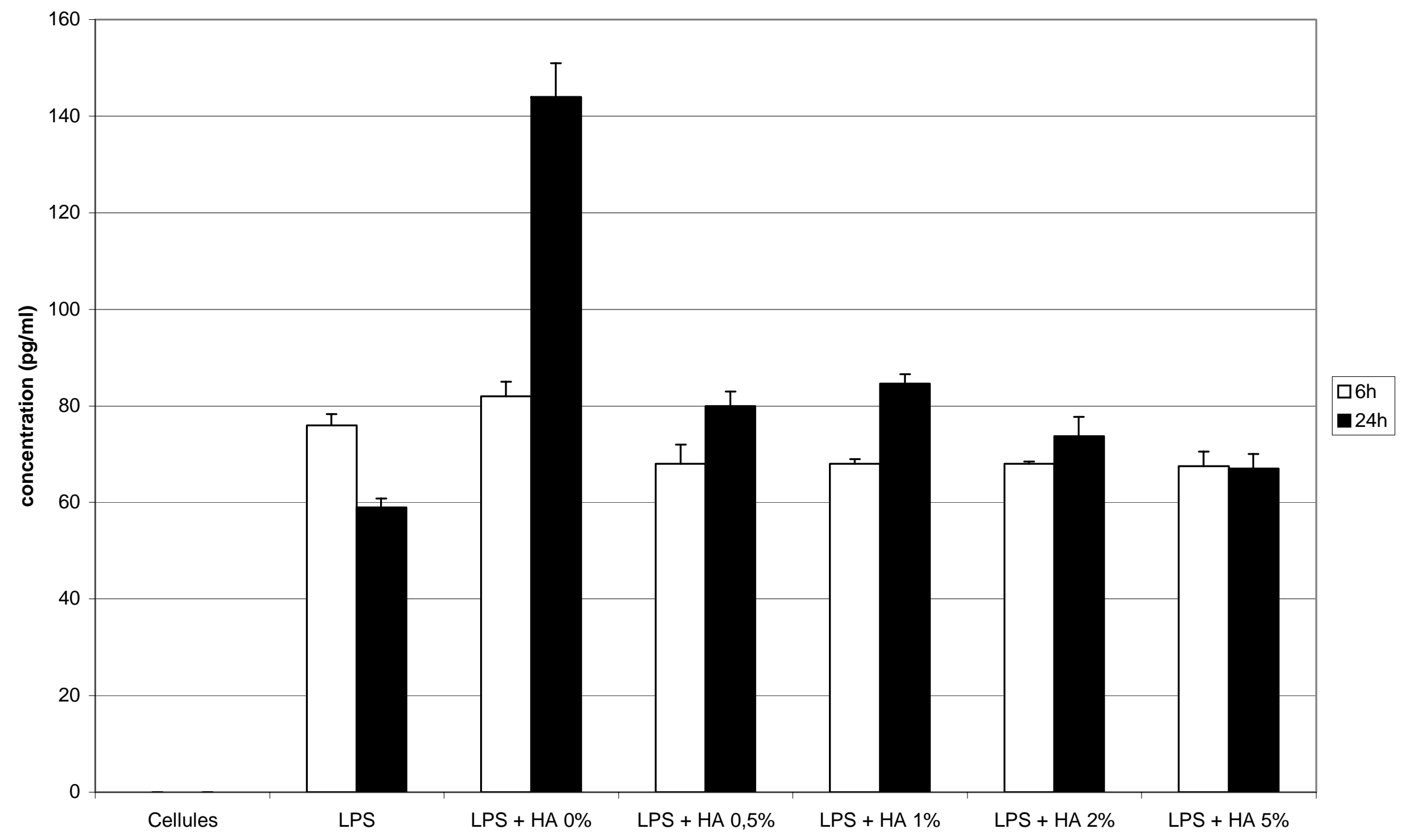

Figure $2 b$ 


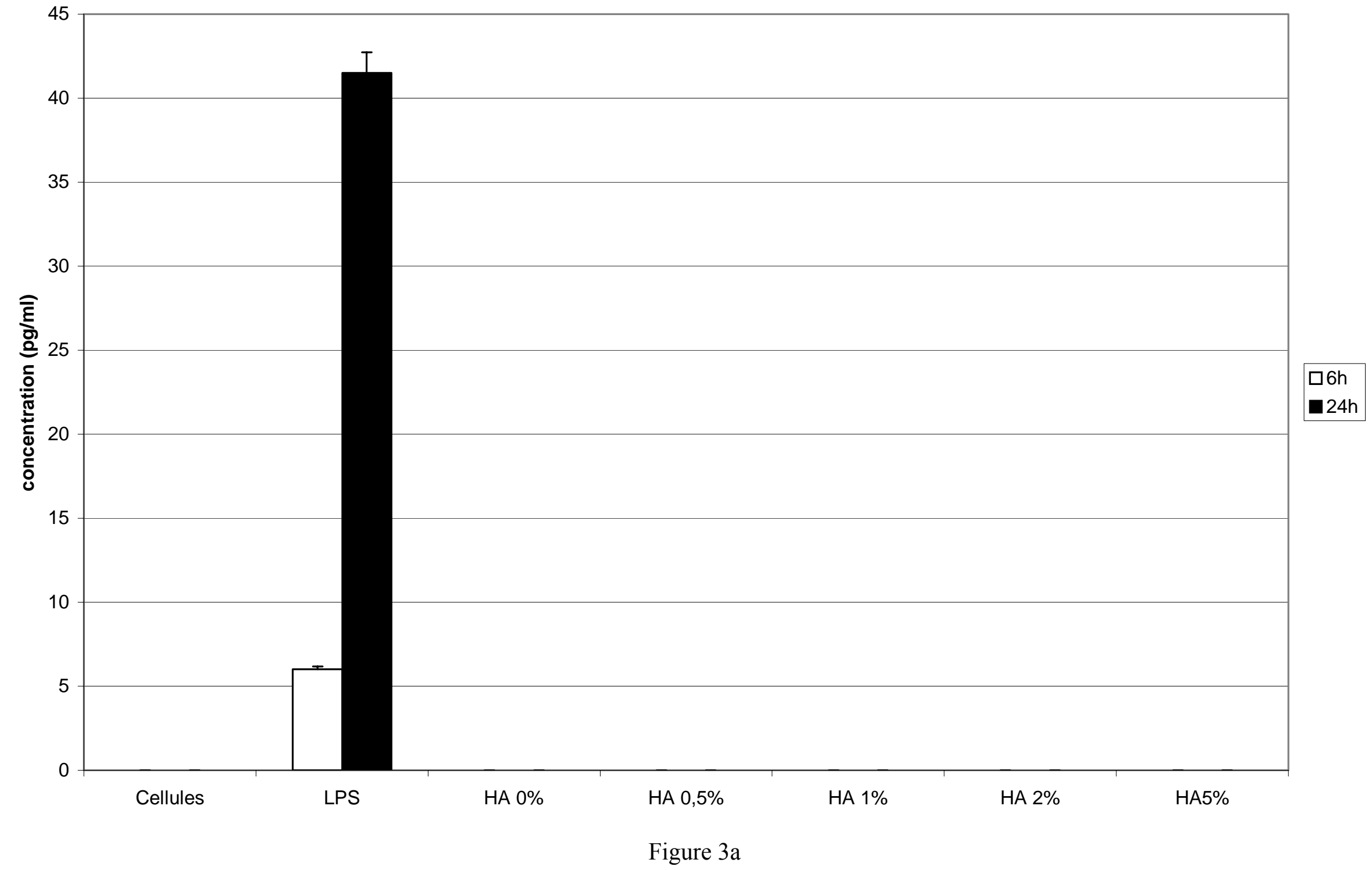




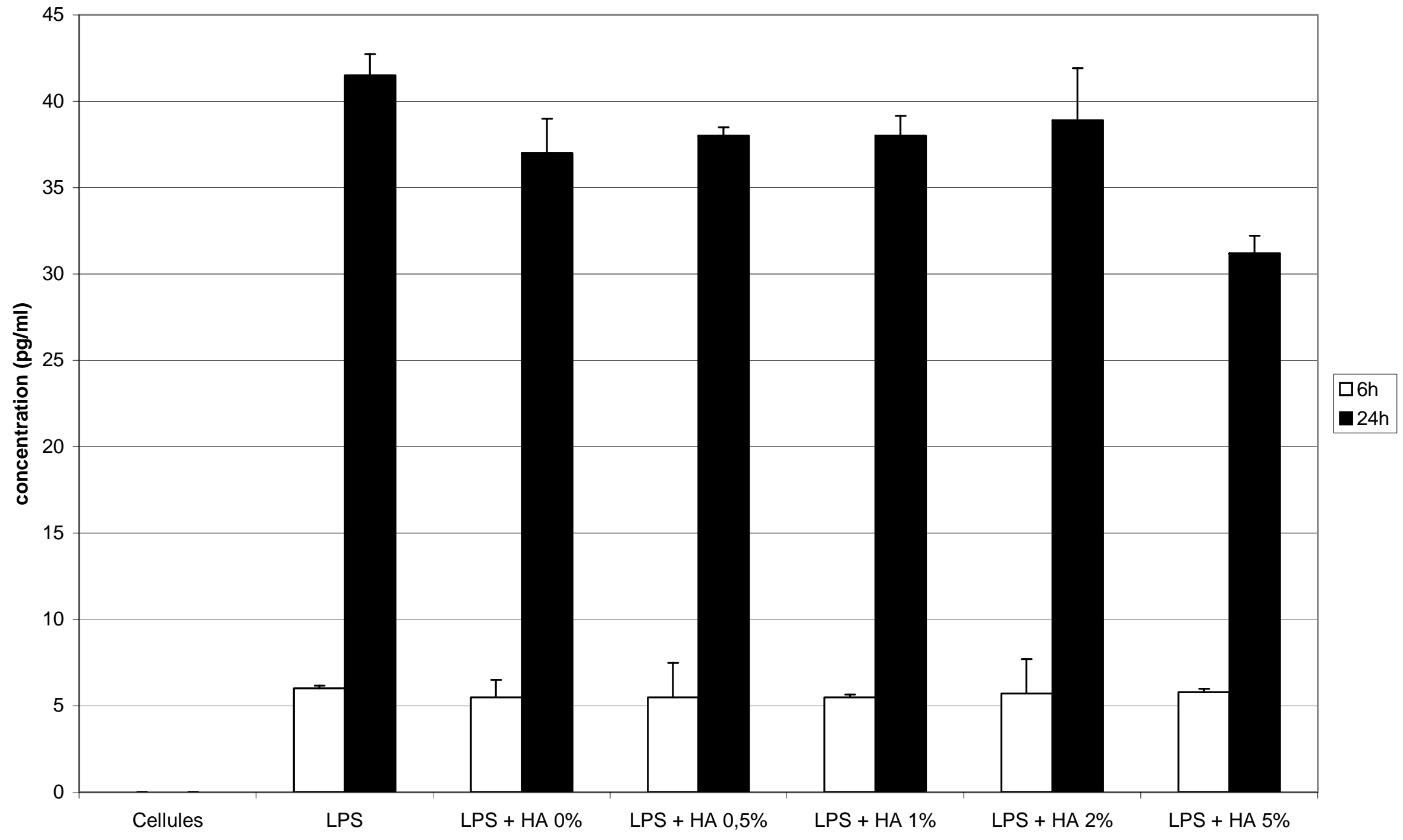

Figure $3 b$ 


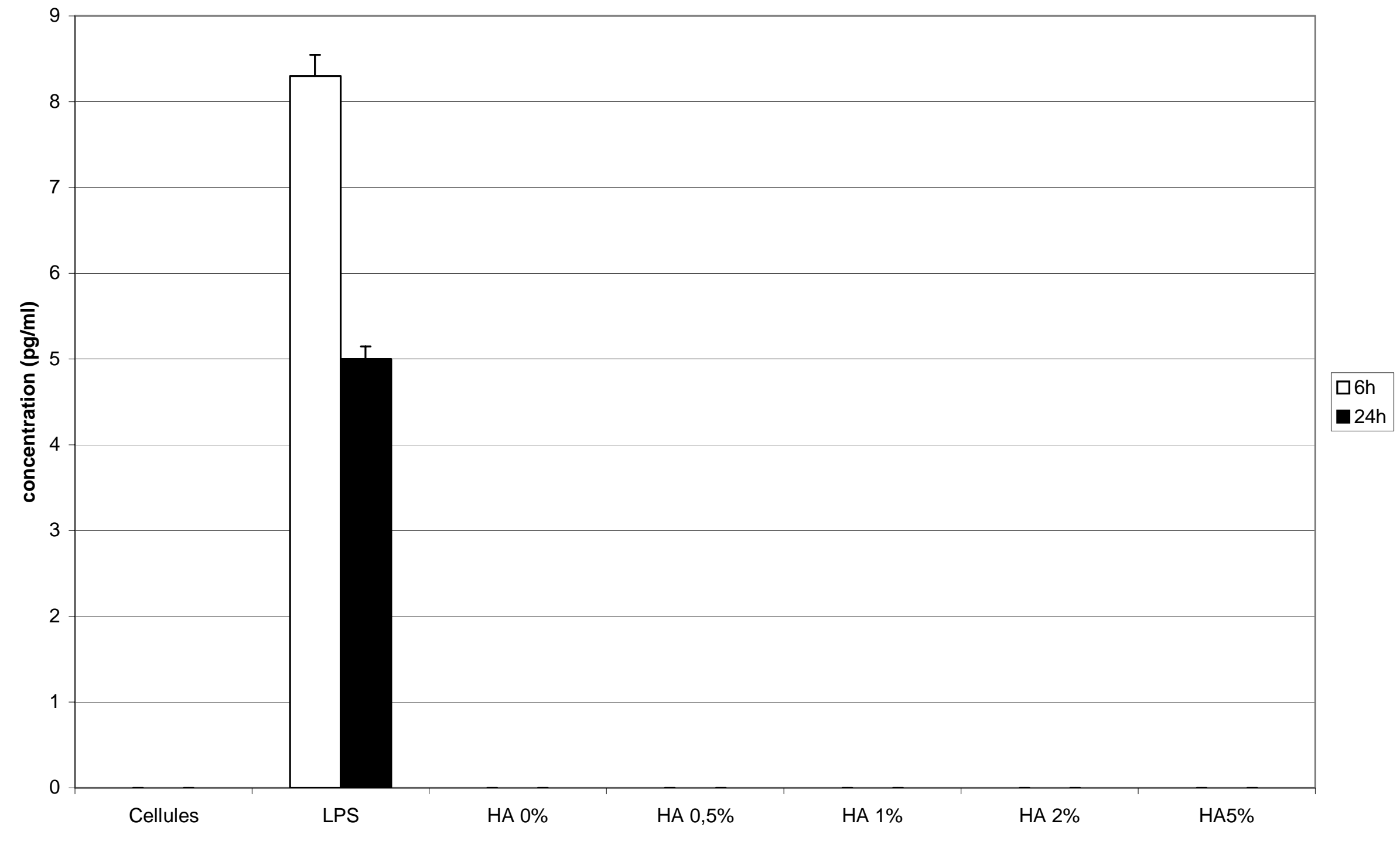

Figure 4a 


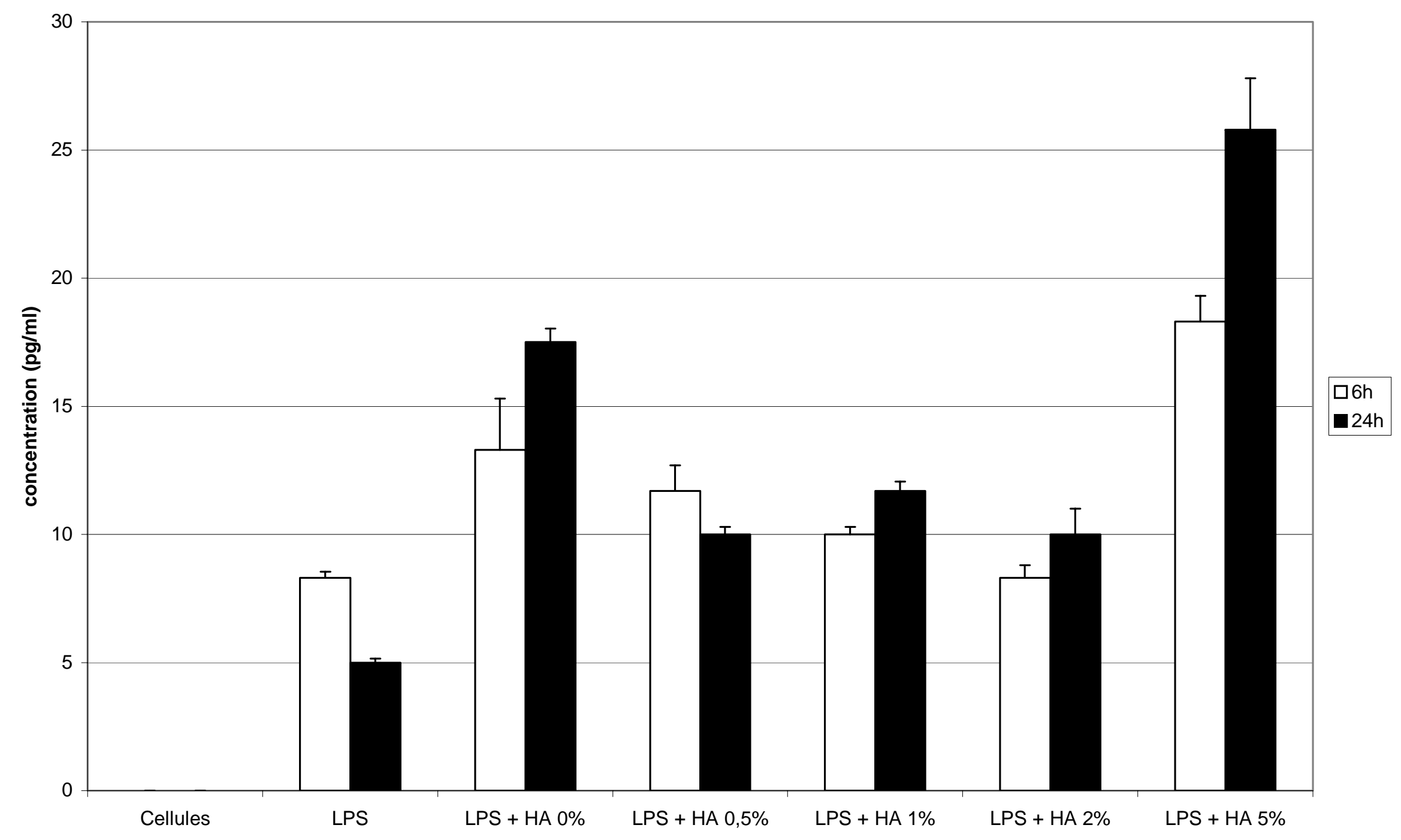

Figure $4 \mathrm{~b}$ 


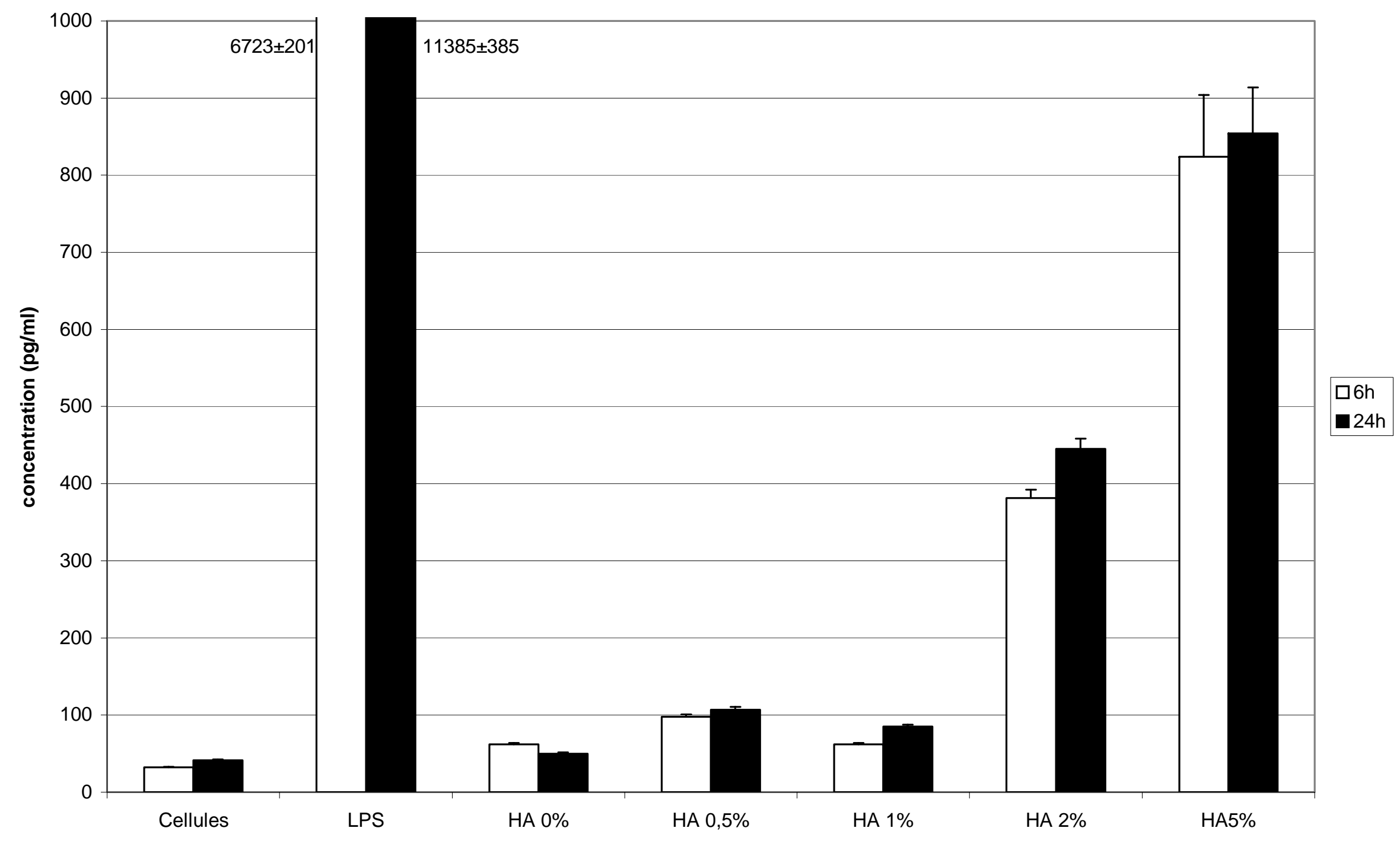

Figure 5a 


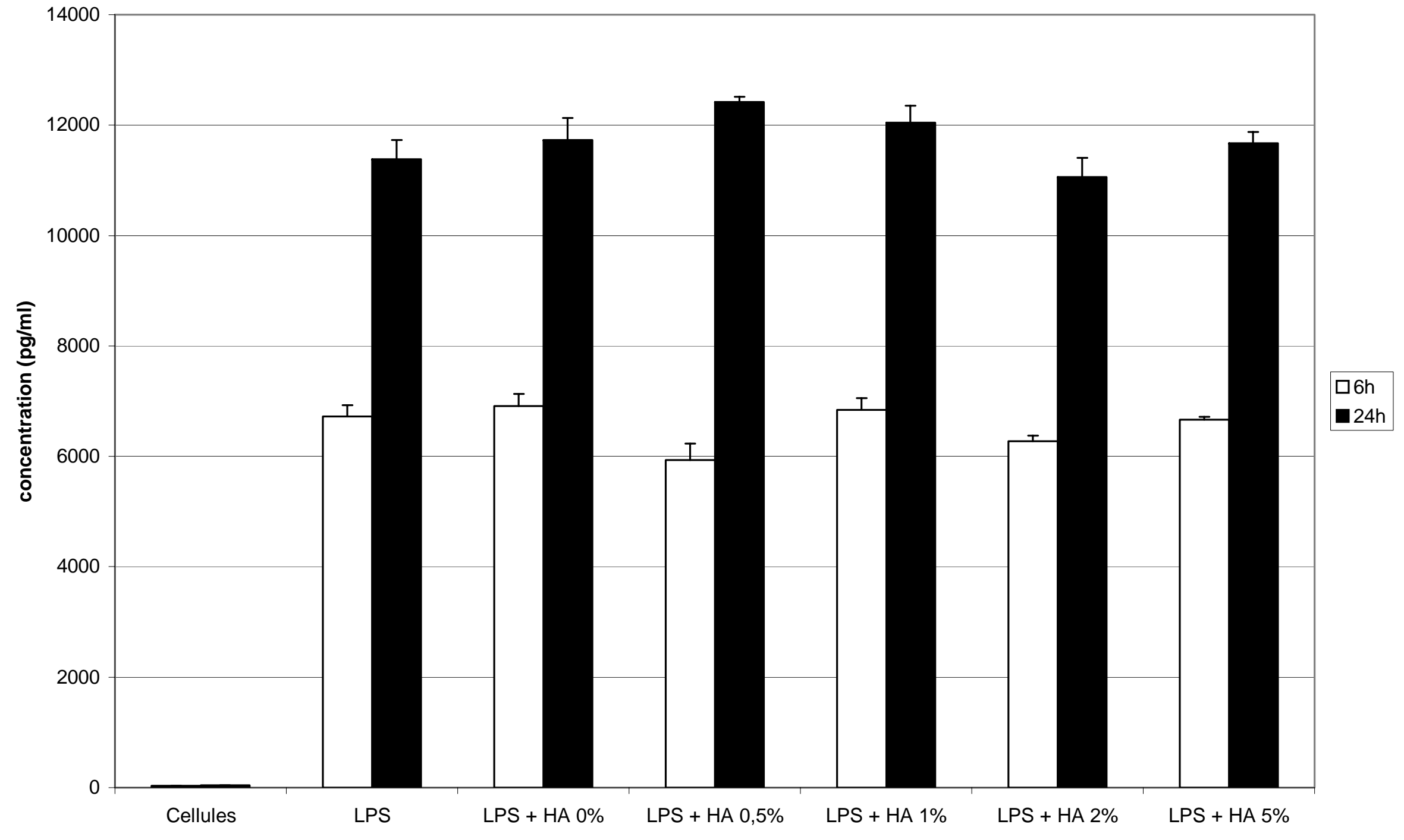

Figure 5b 